\title{
KEDUDUKAN HUTAN ADAT DI ATAS TANAH ULAYAT DALAM PEMANFAATAN HUTAN
}

\author{
Albert Tanjung ${ }^{1}$ \\ ${ }^{1}$ Program Studi Ilmu Hukum, Universitas Nasional \\ email : albert.tanjunglaw@gmail.com
}

Korespondensi : albert.tanjunglaw@gmail.com

\begin{abstract}
Forest is one of the important parts of living things, in it there are plants and animals that humans can use to meet their daily needs. There are 3 (three) forest statuses, customary forest is one of them. Customary forest has become the object of research. Focus on the position of customary forests on ulayat land in forest utilization. Using normative research methods, are descriptive and analyzed qualitatively. From these results, it can be concluded that customary forests are born naturally in the midst of indigenous peoples, decision is only reinforcing proof. The existence of government recognition of ulayat rights provides clarity regarding the position of customary forests that are above ulayat land. This recognition makes the utilization of customary forests by indigenous peoples local not in conflict with the laws and regulations.
\end{abstract}

Keywords: customary forest, ulayat land, forest utilization, position, custom

\begin{abstract}
Abstrak
Hutan adalah salah satu bagian penting bagi kehidupan makhluk hidup, di dalamnya terdapat tumbuh-tumbuhan dan hewan-hewan yang dapat digunakan manusia untuk memenuhi kebutuhan sehari-hari. Ada 3 (tiga) status hutan, hutan adat adalah salah satunya. Hutan adat menjadi objek penelitian. Fokus pada kedudukan hutan adat di atas tanah uayat dalam pemanfaatan hutan. Menggunakan metode penelitian normatif, bersifat deskriptif dan dianalisis secara kualitatif. Dari hasil ini, dapat disimpulkan bahwa hutan adat lahir secara alami di tengah-tengah masyarakat hukum adat, penetapan hanya memperkuat bukti. Adanya pengakuan pemerintah atas hak ulayat memberikan kejelasan tentang kedudukan hutan adat yang berada di atas tanah ulayat. Pengakuan ini membuat pemanfaatan hutan adat oleh masyarakat adat lokal tidak bertentangan dengan hukum dan peraturan.
\end{abstract}

Kata kunci : hutan adat, tanah ulayat, pemanfaatan hutan, kedudukan, adat

\section{PENDAHULUAN}

Indonesia merupakan salah satu negara besar di Asia dan terbesar di Asia Tenggara. Secara geografis dilewati oleh garis khatulistiwa, beriklim tropis dan memiliki kawasan hutan yang sangat luas, sehingga disebut sebagai paru-paru dunia. Berdasarkan data Kementerian Lingkungan Hidup dan Kehutanan Republik Indonesia, Indonesia memiliki kawasan hutan seluas 120 juta hektar. (Peraturan Menteri (Permen) LHK nomor 20 tahun 2018) Dengan kawasan hutan seluas itu 
patut dijaga dan dirawat secara hati-hati agar bermanfaat bagi kehidupan bangsa dan negara. Jika tidak, apalagi hingga menimbulkan kerusakan, maka seluruh potensi manfaat hutan tidak lagi dapat dirasakan, bahkan bisa menimbulkan polusi udara dan penyakit bagi masyarakat. Seperti dalam terjadinya kebakaran, efek yang ditimbulkan sangat berbahaya, tidak hanya bagi lingkungan, tetapi juga bagi kesehatan. Diperlukan adanya kesadaran dari masyarakat untuk menjaga kelestarian dan kemanfataan hutan. Komitmen ini sangat penting, karena kelestarian hutan tidak hanya berguna bagi orang perorangan dan pada saat tertentu, tetapi juga berguna bagi masyarakat dan masa depan.

Perlu diketahui bahwa Indonesia merupakan negara hukum, maka dari itu peraturan perundang-undangan menjadi landasan hukum. Pada dasarnya ketentuan mengenai hutan telah diatur melalui Pasal 33 ayat (3) Undang-undang Dasar Negara Republik Indonesia Tahun 1945 (UUD 1945) yang menyatakan bumi, air dan kekayaan alam yang terkandung di dalamnya dikuasai oleh negara dan dipergunakan untuk sebesar-besar kemakmuran rakyat. Dalam hal ini, hutan termasuk dalam kategori bumi. Oleh karenanya, peraturan-peraturan mengenai hutan juga diatur secara khusus, yang merupakan turunan dari pasal ini. Ditujukan sebagai ramburambu agar kelestarian dan kemanfaatan dapat dijaga dengan baik.

Berdasarkan Pasal 3 ayat (1) dan (2) Peraturan Menteri Lingkungan Hidup dan Kehutanan Nomor: P.32/MENLHK-SETJEN/2015 tentang Hutan Hak (PMLHK 32/2015), status hutan terdiri dari hutan negara, hutan adat dan hutan hak. Hutan hak tersebut terdiri atas hutan adat dan hutan perseorangan. Hutan hak adalah hutan yang berada pada tanah yang dibebani hak atas tanah. Hutan negara merupakan hutan yang berada pada tanah yang tidak dibebani hak atas tanah, sedangkan hutan adat adalah hutan yang berada dalam wilayah masyarakat hukum adat. Agar ditetapkan sebagai hutan adat, masyarakat hukum adat setempat dapat mengajukan permohonan kepada Menteri Lingkungan Hidup dan Kehutanan. Kata dapat berarti tidak ada kewajiban, karena Menteri bersama Pemerintah Daerah bersifat aktif dalam penetapan hutan adat ini.

Jika dirinci berdasarkan oleh Pasal 16 ayat (1) juncto Pasal 53 ayat (1) Undang-undang Nomor 5 Tahun 1960 tentang Peraturan Dasar Pokok-pokok Agraria (UUPA) hak atas tanah terdiri dari hak milik, hak guna usaha, hak guna bangunan, hak sewa, hak membuka tanah, hak memungut hasil hutan dan hak-hak lain yang tidak termasuk dalam hak-hak tersebut yang bersifat sementara, yaitu hak gadai, hak usaha bagi hasil, hak menumpang dan hak sewa tanah pertanian. Hak-hak tersebut masing- masing telah ditentukan. Disamping itu juga ada hak atas tanah lain yang diatur oleh Undang-undang Nomor 20 Tahun 2011 tentang Rumah Susun, yakni hak milik atas satuan rumah susun.

Disini tidak ditemukan adanya hak ulayat sebagai hak atas tanah. Namun Pasal 3 UUPA menyatakan dengan mengingat ketentuan-ketentuan dalam pasal 1 dan 2 pelaksanaan hak ulayat dan hak-hak yang serupa itu dari masyarakatmasyarakat hukum adat, sepanjang menurut kenyataannya masih ada, harus sedemikian rupa sehingga sesuai dengan kepentingan nasional dan negara, yang berdasarkan atas persatuan bangsa serta tidak boleh bertentangan dengan undangundang dan peraturan-peraturan lain yang lebih tinggi. Meskipun bukan merupakan 
hak atas tanah, akan tetapi hak ulayat merupakan suatu hak yang dimilki oleh masyarakat hukum adat terhadap tanah uayat yang diakui oleh negara sebagai milik masyarakat hukum adat. Pasal 1 ayat (3) Peraturan Menteri Negara Agraria Kepala Badan Pertanahan Nasional Nomor 5 Tahun 1999 tentang Pedoman Penyelesaian Masalah Hak Ulayat Masyarakat Hukum Adat (PMA 5/1999) menegaskan bahwa masyarakat hukum adat adalah sekelompok orang yang terikat oleh tatanan hukum adatnya sebagai warga bersama suatu persekutuan hukum karena kesamaan tempat tinggal ataupun atas dasar keturunan dan Pasal 1 ayat (11) PMLHK 32/2015 menyatakan bahwa masyarakat hukum adat adalah kelompok masyarakat yang secara turun temurun bermukim di wilayah geografis tertentu karena adanya ikatan pada asal usul leluhur, adanya hubungan yang kuat dengan lingkungan hidup, serta adanya sistem nilai yang menentukan pranata ekonomi, politik, sosial, dan hukum. Dapat disimpulkan masyarakat hukum adat adalah sekelompok orang yang berasal dari satu keturunan dan terikat pada pranata hukum adat yang sama.

Ketentuan yang berlaku terhadap seluruh hal yang berkaitan dengan hak ulayat adalah aturan hukum adat masyarakat hukum adat setempat. Seperti tanaman, bangunan, hewan ternak, dan hutan. Sebagaimana yang ditentukan oleh Pasal 18B ayat (2) UUD 1945 bahwa negara mengakui dan menghormati kesatuan-kesatuan masyarakat hukum adat beserta hak-hak tradisionalnya sepanjang masih hidup dan sesuai dengan perkembangan masyarakat dan prinsip Negara Kesatuan Republik Indonesia, yang diatur dalam undang-undang.

Layaknya benda-benda adat lainnya, hutan adat dapat dikuasai dengan cara diusahakan dan dimanfaatkan hasilnya. Hal ini tentu boleh dilakukan selama tidak bertentangan dengan ketentuan-ketentuan undang-undang maupun peraturanperaturan yang lebih tinggi sebagaimana dimaksud Pasal 3 UUPA. Contoh, ketika salah satu atau beberapa anggota masyarakat hukum adat mendatangi hutan adatnya dengan tujuan untuk memanen atau mengambil hasilnya, dengan terlebih dahulu mendapat izin dari kepala adat. Hal ini sah untuk dilakukan, namun jika dilakukan dengan tanpa mendapat izin dari kepala adat dan kemudian dilakukan dengan caracara yang dapat merusak hutan, seperti melakukan pembalakan liar, maka hal ini sudah bertentangan dengan undang-undang dan peraturan-peraturan lain yang lebih tinggi, sehingga tidak sah.

Kesimpulannya, masyarakat hukum adat yang ingin melakukan panen dan mengambil hasil hutan adat cukup meminta izin kepada kepala adat dan hal ini bukan merupakan suatu pelanggaran hukum, pidana contohnya. Akan tetapi pada kenyataannya, dibeberapa tempat masih ditemukan penangkapan yang diakibatkan oleh pengambilan hasil hutan adat yang dilakukan oleh masyarakat hukum adat di wilayah hukum adatnya. Inilah yang menjadi masalah, bahwa ternyata masih minimnya pengetahuan dan pemahaman mengenai hak ulayat masyarakat hukum adat atas pengambilan hasil hutan dan pemanfataannya yang berada di wilayah tanah ulayat.

\section{Rumusan Masalah}

Berdasarkan hal-hal tersebut di atas, ternyata terungkap masih terjadi kesalahan dalam implementasi peraturan-peraturan mengenai pemanfaatan hutan 
adat yang pada akhirnya sangat merugikan masyarakat hukum adat. Oleh karenanya, rumusan masalah yang penulis angkat adalah "bagaimanakah kedudukan hutan adat di atas tanah ulayat dalam pemanfaatan hutan? dan apakah pemanfaatan hutan adat hak ulayat oleh masyarakat hukum adat setempat tidak bertentangan dengan peraturan perundang-undangan?".

\section{METODE PENELITIAN}

Penelitian ini termasuk kategori penelitian normatif. Penelitian normatif adalah penelitian yang didasarkan pada studi literatur, telaah buku-buku, perundangundangan, jurnal-jurnal dan atau disebut juga penelitian hukum doktriner, dengan mengambil data sekunder yang ada diperpustakaan (Suratman, 2012) maupun milik pribadi (Hadikusuma,1995). Berdasarkan sifatnya, penelitian ini bersifat deskriptif dan dianalisa secara kualitatif agar dapat mengeksplorasi kedudukan hutan adat di atas tanah ulayat dalam pemanfaatan hutan.

\section{HASIL DAN PEMBAHASAN \\ Hutan Adat Di Atas Tanah Ulayat Dalam Pemanfaatan Hutan Tanah Ulayat}

Terdapat beberapa persoalan yang bekaitan dengan tanah ulayat, misalnya dalam hal pemanfataan hutan yang berada di dalam tanah ulayat oleh masyarakat hukum adat. Padahal tanah ulayat merupakan milik masyarakat hukum adat itu sendiri. Sebenarnya tanah ulayat merupakan suatu wilayah yang mengandung hak ulayat. Jadi harus dipahami bahwa seluruh benda yang ada di atasnya dapat dimanfaatkan oleh pemiliknya. Sebagaimana Pasal 1 ayat (2) PMA 5/1999 menyatakan, tanah ulayat adalah bidang tanah yang di atasnya terdapat hak ulayat dari suatu masyarakat hukum adat tertentu. Dapat disimpulkan tanah ulayat dan hak ulayat adalah satu kesatuan yang tidak dapat dipisahkan. Tanah ulayat sebagai wilayah dan hak ulayat sebagai hak yang terkandung di dalamnya.

Oleh karennya, tidak kalah penting untuk dijabarkan mengenai hak ulayat. Definisi hak ulayat tersebar pada beberapa sumber hukum, seperti peraturan perundang-undangan maupun doktrin. Definisi-definisi tersebut antara lain:

1. Hak ulayat adalah kewenangan yang menurut hukum adat dipunyai oleh masyarakat hukum adat tertentu atas wilayah tertentu yang merupakan wilayah hidup para warganya untuk mengambil manfaat dari sumber daya alam, termasuk tanah dalam wilayah tersebut, bagi kelangsungan hidup dan kehidupannya, yang timbul dari hubungan secara lahiriah dan batiniah turun temurun dan tidak terputus antara masyarakat hukum adat tersebut dengan wilayah yang bersangkutan (Pasal 1 ayat (1) PMA 5/1999);

2. Hak ulayat adalah adalah hak milik bersama masyarakat hukum adat yang diakui oleh pemerintah atau Pemerintah Daerah sesuai dengan peraturan perundang-undangan (Pasal 1 ayat (10) PMLHK 32/2015);

3. Hak ulayat adalah hak persekutuan hukum masyarakat hukum adat (nagari, marga, desa, suku, keturunan dan lainnya) atas lingkungan tanah (hutan) yang belum dibuka atau dikerjakan. (Hadikusuma : 2001) 
Maka dapat ditarik suatu kesimpulan bahwa yang dimaksud dengan hak ulayat adalah kewenangan yang menurut hukum adat dimiliki oleh masyarakat hukum adat tertentu secara turun termurun atas wilayah tertentu yang merupakan wilayah hidup para warganya untuk mengambil manfaat dari sumber daya alam, termasuk tanah dan hutan dalam wilayah tersebut, baik yang sudah maupun yang belum dibuka atau dikerjakan guna kelangsungan hidup sehari-hari dan diakui oleh pemerintah.

Keberadaan tanah ulayat jelas telah diakui oleh pemerintah, hal ini dapat ditemui di dalam Pasal 3 UUPA yang menyatakan dengan mengingat ketentuanketentuan dalam pasal 1 dan 2 pelaksanaan hak ulayat dan hak-hak yang serupa itu dari masyarakat-masyarakat hukum adat, sepanjang menurut kenyataannya masih ada, harus sedemikian rupa sehingga sesuai dengan kepentingan nasional dan negara, yang berdasarkan atas persatuan bangsa serta tidak boleh bertentangan dengan undang-undang dan peraturan-peraturan lain yang lebih tinggi. Disamping itu, kewenangan yang diberikan pemerintah atas penguasaan hak ulayat dinyatakan secara tegas di dalam ketentuan Pasal 2 ayat (4) UUPA, yang menyatakan hak menguasai dari negara tersebut di atas pelaksanaannya dapat dikuasakan kepada daerahdaerah Swatantra dan masyarakat-masyarakat hukum adat, sekedar diperlukan dan tidak bertentangan dengan kepentingan nasional, menurut ketentuanketentuan Peraturan Pemerintah. Artinya, selama tanah dan hak ulayat itu masih ada, maka pemerintah mengakui dan menghormati keberadaannya. Lebih jauh, peraturan-peraturan yang beralaku di atas tanah ulayat tersebut adalah hukum adat setempat. Hak ulayat memiki kodrat berada secara alamiah ditengah-tengah masyarakat.

Masyarakat hukum adat memiliki beberapa hak dalam penguasaan maupun pemanfataan tanah ulayat. Hak-hak ini dibagi berdasarkan pemanfataannya, yaitu hak memungut hasil hutan, hak membuka tanah, hak utama dan hak bersama. Masing-masing penjelasannya sebagai berikut: (Hadikusuma, 2001).

1. Hak memungut hasil hutan adalah hak masyarakat hukum adat untuk memungut hasil hutan. Terutama kayu petukangan untuk keperluan bangunan, kayu bakar, rotan, arang damar, bambu, hasil berburu berbagai jenis binatang seperti kulit, tanduk dan gading, serta bebarbagi jenis umbi, buah-buahan, kemenyan dan lainnya;

2. Hak membuka tanah adalah hak masyarakat hukum adat untuk mengusahakan sebidang tanah;

3. Hak utama atau yang juga disebut hak wenang pilih adalah hak masyarakat hukum adat untuk lebih diutamakan terhadap tanah yang akan dibukanya, apabila di atas tanah itu terdapat tanda-tanda mebali, berupa tanda silang diranting yang diikat dengan rotan di atas pohon atau pada batang pohon itu terdapat tanda-tanda kupasan kulitnya atau disekitarna terdapat tanda-tanda ikatan kayu atau belahan bambu berdiri disekitarnya. Adanya tanda mebali mengartikan adanya hak utama bagi pembuatnya untuk diutamakan atau untuk memilih apakah tanah tersebut akan terus diusahakan atau tidak;

4. Hak bersama atau yang disebut juga tanah kerabat (familie bezitrecht) adalah hak-hak anggota kerabat untuk menikmati hasil atau memungut hasil, 
mengusahakan tanah dengan cara menempati dan menanam di bawah pengawasan kepala kerabat menurut susunan keturunan masing-masing.

Pada dasarnya seluruh hak yang terkandung di dalam hak ulayat merupakan hak penguasaan atas tanah yang dimiliki oleh masyarakat hukum adat dan diakui oleh pemerintah, sehingga segala bentuk pemanfaatan di atasnya adalah sah menurut hukum, selama tidak dilakukan dengan cara-cara yang bertentangan dengan peraturan perundang-undangan, kesusilaan dan ketertiban umum. Begitu pula halnya dengan hutan adat yang terdapat di dalam kawasan tanah ulayat.

\section{Hutan Adat}

Hutan merupakan salah sau bagian penting dalam kehidupan, karena banyaknya peran yang dimiliki, seperti ekosistem, bahan makanan yang berasal dari tumbuh-tumbuhan dan hewan, penyerapan air, sumber penghasil oksigen dan lain sebagainya. Tidak dapat dipungkiri, keberadaan hutan harus dilestarikan, disatu sisi berguna sebagai sesuatu yang manfaatnya dapat digunakan untuk kehidupan manusia dan disisi lainnya juga berguna bagi kelangsungan hidup aneka flora dan fauna yang berada di dalamnya. Tentunya pemanfaatan ini dilaksanakan sesuai dengan peraturan-peraturan yang mengatur mengenai hutan, terutama pemanfaatannya. Agar dilaksanakan secara disiplin dan tertib, sehingga tidak mengakibatkan kerusakan. Akibat yang ditimbulkan dari kerusakan hutan tidak hanya untuk hutan dan eksosistemnya, tetapi juga berdampak buruk pada kehidupan dan lingkungan makhluk hidup secara keseluruhan. Hal ini berlaku pada seluruh hutan, baik itu hutan negara, hutan adat, maupun hutan hak.

Pada pokoknya, menurut Pasal 1 ayat (1) Undang-undang Nomor 18 Tahun 2013 tentang Pencegahan dan Pemberantasan Perusakan Hutan (UU P3H) juncto Pasal 1 ayat (2) Undang-undang Nomor 41 Tahun 1999 tentang Kehutanan sebagaimana telah diubah dengan Undang-Undang Nomor 19 Tahun 2004 tentang Penetapan Peraturan Pemerintah Pengganti UndangUndang Nomor 1 Tahun 2004 tentang Perubahan atas Undang-undang Nomor 41 Tahun 1999 tentang Kehutanan Menjadi Undang-Undang (UUK) juncto Pasal 1 ayat (1) PMLHK 32/2015 hutan adalah hutan adalah suatu kesatuan ekosistem berupa hamparan lahan berisi sumber daya alam hayati yang didominasi pepohonan dalam komunitas alam lingkungannya yang tidak dapat dipisahkan antara yang satu dan yang lainnya. Kemudian menurut Pasal 1 ayat (6) UUK juncto Putusan Mahkamah Konstitusi Republik Indonesia Nomor 35/PUU-X/2012 (MK 35/2012) juncto Pasal 1 ayat (6) PMLHK 32/2015 juncto Pasal 1 ayat (12) Peraturan Menteri Lingkungan Hidup dan Kehutanan Nomor P.83/MENLHK/SETJEN/KUM.1/10/2016 tentang Perhutanan Sosial (PMLHK 83/2016) pada pokoknya menyatakan bahwa hutan adat adalah hutan yang berada di wilayah masyarakat hukum adat. Wilayah itu tidak lain adalah tanah ulayat.

Selama hak ulayat masih ada, maka selama itu pula hutan adat ada, karena hutan adat merupakan bagian dari tanah ulayat. Setiap anggota masyarakat hukum adat yang memiliki tanah ulayat, berhak untuk memanfaatkan tanah tersebut sesuai dengan sistem kekerabatan yang dianut. Orang luar tidak dapat memiliki hak demikian, karena bukan merupakan anggota masyarakat. Dalam perkembangannya, 
orang luar hanya dapat mengambil manfaat dengan jalan menikah, waris dan hibah. Itupun tidak berarti dengan proses-proses demikian orang luar dapat menjadi pemilik secara permanen. Yang bisa didapat hanyalah hak menggunakan atau menumpang saja. Jika bagian dari hutan adat itu dihibahkan, maka penghibahan ini hanya bersifat sementara, minimal ketika meninggal. Hutan ini kembali kepada penghibah. Hal ini disebabkan karena pada prinsipnya harta pusaka yang dalam hal ini hutan adat tidak dapat dialihkan kepada pihak manapun.

Dalam pernikahan, yang bersangkutan hanya ikut menikmati hak yang dimiliki oleh pasangan kawin, begitupun halnya dengan waris. Jika ternyata menurut sistem kekerabatan yang dianut pewaris orang ini tidak dapat mewaris, maka tanah ulayat maupun hutan adat tidak dapat beralih kepada ahli waris, meskipun anak kandung. Perlu diketahui bahwa adat 3 (tiga) sistem kekerabatan dalam hukum adat, yaitu matrilineal, patrilineal dan parental atau bilateral. Matrilineal adalah sistem kekerabatan yang menarik garis keturunan ibu. Patrilineal adalah sistem kekerabatan yang menarik garis keturunan bapak dan sistem kekerabatan parental atau bilaterah adalah sistem kekerabatan yang menarik garis keturunan kedua orang tua. Setelah memperhatikan sistem kekerabatan, selanjutnya yang tidak kalah penting adalah sistem pewarisannya.

Berbeda halnya jika hak ulayat itu sudah tidak ada, maka tanah yang sudah tidak memiliki hak ulayat tidak lagi dapat kembali ataupun dikembalikan statusnya menjadi hak ulayat. Tidak lagi adanya hak ulayat dapat terjadi karena transaksi yang pada akhirnya memunculkan suatu bukti hak, contohnya sertipikat hak milik. Keberadaan sertipikat ini secara otomatis menghilangkan status hak ulayat atas tanah tersebut. Konsekuensinya, tanah yang demikian ini tidak dapat dikembalikan atau kembali statusnya menjadi hak ulayat.

Sebagai peraturan perundang-undangan yang tertinggi dalam hirarki perundang-undangan, UUD 1945 menjadi landasan hukum utama. Dengan adanya Pasal 18B ayat (2) yang kemudian diperkuat dengan Pasal 3 UUPA, secara hukum telah membuktikan bahwa negara mengakui keberadaan hak ulayat termasuk juga hutan adat sebagai bagian dari tanah ulayat. Ada atau tidak adanya penetapan tidak menjadi persoalan, karena sebetulnya hal tersebut merupakan persyaratan administratif yang dirancang dengan tujuan untuk memperkuat legal standing tanah dan hutan tersebut. Bukan berarti dengan tidak adanya penetapan dari pemerintah, kemudian meniadakan hutan adat.

\section{Pemanfaatan Hutan Adat Hak Ulayat Oleh Masyarakat Hukum Adat Setempat}

Muncul berbagai macam persoalan yang berhubungan dengan pemanfaatan hutan, baik itu hutan hak, hutan negara maupun hutan adat. Tidak main-main, setiap pelangaran hukum ini dapat dijerat dengan hukum pidana, penindakannya sangat tegas dalam upaya preventif maupun represif yang dilaksanakan dengan tujuan agar tidak ada lagi penyalahgunaan pemanfataan hutan yang dapat berakibat kerusakan pada hutan. Pasal 1 ayat (9) UU P3H juncto Pasal 1 ayat (17) PMLHK 32/2015 juncto Pasal 1 ayat (8) PMLHK 83/2016 menyatakan pemanfaatan hutan adalah adalah kegiatan untuk memanfaatkan kawasan hutan dalam bentuk hasil hutan kayu 
dan bukan kayu melalui pembibitan, penanaman, pemeliharaan, pemanenan, pengolahan, dan pemasaran berdasarkan asas kelestarian hutan, sosial dan lingkungan atau dalam bentuk pemanfaatan jasa lingkungan melalui antara lain jasa ekowisata, jasa tata air, jasa keanekaragaman hayati, jasa penyimpanan karbon.

Hutan adat dapat dimanfaatkan sebagai usaha pertanian untuk mengambil hasil hutan berupa kayu, karet dan lainnya. Sebagai contoh menebang pohon untuk mengambil kayu, kayu ini bisanya digunakan sebagai bahan untuk membangun bangunan dan juga dapat digunakan sebagai kayu bakar. Pada prinsipnya hutan adat hadir secara alami mengikuti hak ulayat yang melekat pada tanah masyarakat hukum adat. Tidak diperlukan adanya suatu penetapan status, namun agar memiliki legitimasi yang jelas, maka hal ini diperlukan. Pasal 50 ayat (1) PMLHK 83/2016 menyebutkan bahwa masyarakat hukum adat dapat mengajukan permohonan hutan hak untuk ditetapkan sebagai kawasan hutan hak kepada menteri yang berwenang dibidang lingkungan hidup dan kehutanan. Kata dapat ini memberikan makna permohonan itu tidak wajib diajukan. Sehingga meskipun tidak ada penetapan, hutan adat itu diakui keberadaannya.

Menurut peraturan perundang-undangan, subjek hukum pemilik hak mengurus hutan hak disebut sebagai pemangku hutan hak. Yang dapat menjadi pemangku ini adalah masyarakat hukum adat, perseorangan secara sendiri-sendiri maupun bersama-sama dalam kelompok atau badan hukum yang memiliki hak untuk mengurus hutan hak. Masyarakat hukum adat ini adalah masyarakat hukum adat setempat, perseorangan yang dimaksud adalah warga negara Indonesia dan maksud secara bersama-sama adalah sekelompok masyarakat dalam wilayah tertentu. Selanjutnya badan hukum yang dimaksud disini adalah koperasi yang dibentuk oleh masyarakat setempat. Khusus badan hukum, diperlukan akta pendirian beserta perubahan-perubahannya saat pengajuan permohonan.

Agar dapat menjadi pemangku hutan hak, pihak-pihak tersebut dapat mengajukan permohonan penetapan kawasan hutan kepada menteri yang diserahi tugas dan bertanggung jawab di bidang lingkungan hidup dan kehutanan. Persyaratannya tergantung kepada status hutan yang dimohonkan. Pertama, permohonan penetapan hutan hak perseorangan atau badan hukum adalah (Pasal 5 PMLHK 32/2015):

1. Terdapat hak atas tanah yang dimiliki oleh perseorangan atau badan hukum yang dibuktikan dengan dokumen-dokumen tertulis atau bukti-bukti tidak tertulis sebagaimana diatur dalam peraturan perundang-perundangan;

2. Terdapat tanah yang sebagian atau seluruhnya berupa hutan;

3. Surat pernyataan dari perseorangan/badan hukum untuk menetapkan tanahnya sebagai hutan hak.

Kedua, permohonan penetapan hutan adat, syarat-syaratnya adalah sebagai berikut (Pasal 6 PMLHK 32/2015):

1. Terdapat masyarakat hukum adat atau hak ulayat yang telah diakui oleh pemerintah daerah melalui produk hukum daepeta wilayah adat, maka Menteri bersama-sama dengan pemerintah daerah menfasilitasi masyarakat hukum adat untuk melakukan pemetaan wilayah adatnya);

2. Terdapat wilayah adat yang sebagian atau seluruhnya berupa hutan; 
3. Surat pernyataan dari masyarakat hukum adat untuk menetapkan wilayah adatnya sebagai hutan adat.

Menurut Pasal 1 ayat (2) PMLHK 32/2015, 2. kawasan hutan adalah wilayah tertentu yang ditetapkan oleh pemerintah untuk dipertahankan keberadaannya sebagai hutan tetap dan ayat (3) menyebutkan bahwa hutan tetap adalah kawasan hutan yang akan dipertahankan keberadaannya sebagai kawasan hutan, terdiri dari hutan konservasi, hutan lindung, hutan produksi terbatas dan hutan produksi tetap. Penetapan inilah yang diurus oleh pemangku hak tanah agar mendapat pengakuan, perlindungan dan insentif dari pemerintah dalam mengurus hutannya. Setelah kawasan ditetapkan, muncul hak dan kewajiban. Hak dan kewajiban ini sebagaimana dimaksud Pasal 10 PMLHK 32/2015. Hak-haknya adalah sebagai berikut:

1. Mendapat insentif;

2. Mendapat perlindungan dari gangguan perusakan dan pencemaran lingkungan;

3. Mengelola dan memanfaatkan hutan hak sesuai dengan kearifan lokal;

4. Memanfaatkan dan menggunakan pengetahuan tradisional dalam pemanfaatan sumber daya genetik yang ada di dalam hutan hak;

5. Mendapat perlindungan dan pemberdayaan terhadap kearifan lokal dalam perlindungan dan pengelolaan hutan hak;

6. Memanfaatkan hasil hutan kayu, bukan kayu dan jasa lingkungan sesuai dengan fungsi kawasan hutan;

7. Memperoleh sertifikat Legalitas Kayu.

Adapun kewajiban-kewajibannya, yaitu:

1. Mempertahankan fungsi hutan hak;

2. Menjalankan prinsip-prinsip pengelolaan hutan lestari;

3. Memulihkan dan meningkatkan fungsi hutan;

4. Melakukan pengamanan dan perlindungan terhadap hutannya antara lain perlindungan dari kebakaran hutan dan lahan.

Pada intinya, pemangku hak hutan memiliki hak pemanfaatan hutan dan sekaligus kewajiban untuk terus menjaga kelestarian dan fungsi hutan agar tidak terjadi kerusakan, sehingga fungsi yang ada pada hutan tersebut dapat tetap terjaga. Walaupun sebenarnya untuk pengamanan dan perlindungan hutan sudah ada Polisi Kehutanan. Berdasarkan Pasal 1 ayat (15) UU P3H, Polisi Kehutanan adalah pejabat tertentu dalam lingkup instansi kehutanan pusat dan/atau daerah yang sesuai dengan sifat pekerjaannya menyelenggarakan dan/atau melaksanakan usaha pelindungan hutan yang oleh kuasa undang-undang diberikan wewenang kepolisian khusus di bidang kehutanan dan konservasi sumber daya alam hayati dan ekosistemnya yang berada dalam satu kesatuan komando.

Lain halnya dengan subjek hukum di dalam hutan adat, sesuai dengan hukum adat yang dianut oleh masyarakat hukum adat itu dan sistem kekerabatan. Ketika salah seorang dari anggota masyarakat hukum adat melakukan mebali terhadap area hutan adat tertentu, maka orang inilah yang berhak untuk memanfaatkan area tersebut. Sesederhana itu, tidak diperlukan penetapan ataupun syarat-syarat dalam bentuk tertulis untuk mendapatkan melakukan pemanfaatan 
hutan adat. Apbila izin dari kepala dat telah didapat, maka pemanfaatan dapat dilakukan. Hanya saja kepemilikan tetap secara bersama atas hutan adat maupun tanah ulayat ini. Tidak diperkenankan untuk dialihkan kepada pihak lain, misalkan dijual. Konsep kepemilikan tanah ulayat dalam hukum adat adalah selama-lamanya, hal ini diakukan juga untuk menghindari hilangnya status hak ulayat atas tanah yang telah dikuasai masyarakat hukum adat. Dengan demikian, praktek-praktek pemanfaatan hutan adat yang dilaksanakan ole masyarakat hukum adat adalah sah dan tidak melanggar hukum.

Di dalam hukum adat tugas menjaga hutan adat yang telah dihaki oleh anggota masyarakat hukum adat adalah pemilik hak tersebut. Akan tetapi, jika yang bersangkutan melakukan pemanfaatan hutan dengan cara-cara yang mengakibatkan rusaknya hutan, maka kepala adat dapat menjatuhkan hukuman adat terhadap pelaku. Ketetuan ini berlaku sebatas pada wilayah masyarakat adat tertentu atau itu saja. Secara nasional terdapat Undang-undang Nomor 18 Tahun 2013 tentang Pencegahan dan Pemberantasan Perusakan Hutan yang secara tegas memberi rambu-rambu hukuman atas setiap tindakan pemanfaatan yang berujung kepada perusakan hutan. Pasal 12 menyatakan setiap orang dilarang untuk:

1. Penebangan pohon dalam kawasan hutan yang tidak sesuai dengan izin pemanfaatan hutan;

2. Melakukan penebangan pohon dalam kawasan hutan tanpa memiliki izin yang dikeluarkan oleh pejabat yang berwenang;

3. Melakukan penebangan pohon dalam kawasan hutan secara tidak sah;

4. Memuat, membongkar, mengeluarkan, mengangkut, menguasai, dan/atau memiliki hasil penebangan di kawasan hutan tanpa izin;

5. Mengangkut, menguasai, atau memiliki hasil hutan kayu yang tidak dilengkapi secara bersama surat keterangan sahnya hasil hutan;

6. Membawa alat-alat yang lazim digunakan untuk menebang, memotong, atau membelah pohon di dalam kawasan hutan tanpa izin pejabat yang berwenang;

7. Membawa alat-alat berat dan/atau alat-alat lainnya yang lazim atau patut diduga akan digunakan untuk mengangkut hasil hutan di dalam kawasan hutan tanpa izin pejabat yang berwenang;

8. Memanfaatkan hasil hutan kayu yang diduga berasal dari hasil pembalakan liar;

9. Mengedarkan kayu hasil pembalakan liar melalui darat, perairan, atau udara;

10. Menyelundupkan kayu yang berasal dari atau masuk ke wilayah Negara Kesatuan Republik Indonesia melalui sungai, darat, laut, atau udara;

11. Menerima, membeli, menjual, menerima tukar, menerima titipan, dan/atau memiliki hasil hutan yang diketahui berasal dari pembalakan liar;

12. Membeli, memasarkan, dan/atau mengolah hasil hutan kayu yang berasal dari kawasan hutan yang diambil atau dipungut secara tidak sah; dan/atau menerima, menjual, menerima tukar, menerima titipan, menyimpan, dan/atau memiliki hasil hutan kayu yang berasal dari kawasan hutan yang diambil atau dipungut secara tidak sah. 
Setiap orang yang dimaksud adalah tidak sebatas pada orang perseorangan, tetapi juga termasuk korporasi yang melakukan perbuatan perusakan hutan secara terorganisir di wilayah hukum Indonesia dan/atau berakibat hukum di wilayah Indonesia. Berbeda dengan tindak pidana yang diatur di dalam Undang-undang Nomor 41 Tahun 1999 tentang Kehutanan juncto Putusan Mahkamah Konstitusi Nomor 35/PUU-X/2012. UU P3H hanya dapat menjerat perbuatan perusakan hutan yang dilakukan secara terorganisir, sedangkan di dalam UUK, hal demikian tidak ditentukan. Undang-undang ini dapat menjadi solusi untuk menjerat pelaku perusakan hutan yang dilakukan secara manual dan tidak terorganisir.

Tampak jelas bahwa pemanfaatan hutan adat oleh masayarakat hukum adat bukan merupakan perbuatan yang melanggar hukum dan sama sekali tidak bertentangan dengan ketentuan peraturan perundang-undangan. Justru peraturan perundang-undang telah mengakomodir keberadaan hutan adat dengan sistem hukum adat, sehingga dapat dilaksanakan guna memenuhi kebutuhan sehari-hari dengan tanpa menghilangkan ketentuan-ketentuan yang dianut secara temurun temurun, khususnya mengenai tanah ulayat (Sulaiman, 2019).

\section{SIMPULAN}

Kedudukan hutan adat di atas tanah ulayat dalam pemanfaatan hutan mengikuti hak ulayat yang melekat di atas tanah tersebut. Selama hak ulayat masi berada di atas tanah masyarakat hukum adat dan di dalam bagiannya terdapat hutan adat, selama itu pula hutan adat ada. Kedudukannya jelas dijamin oleh peraturan perundang-undangan. Sebagaimana definisi masing-masing, tanah ulayat adalah bidang tanah yang di atasnya terdapat hak ulayat dari suatu masyarakat hukum adat tertentu, sedangkan hak ulayat adalah kewenangan yang menurut hukum adat dimiliki oleh masyarakat hukum adat tertentu secara turun termurun atas wilayah tertentu yang merupakan wilayah hidup para warganya untuk mengambil manfaat dari sumber daya alam, termasuk tanah dan hutan dalam wilayah tersebut, baik yang sudah maupun yang belum dibuka atau dikerjakan guna kelangsungan hidup seharihari dan diakui oleh pemerintah.

Sesuai dengan Pasal 18B ayat (2) UUD 1945 juncto Pasal 3 UUPA yang menegaskan bahwa negara mengakui dan menghormati kesatuan-kesatuan masyarakat hukum adat beserta hak-hak tradisionalnya sepanjang masih hidup dan sesuai dengan perkembangan masyarakat dan prinsip Negara Kesatuan Republik Indonesia, yang diatur dalam undang-undang dan dengan mengingat ketentuanketentuan dalam pasal 1 dan 2 pelaksanaan hak ulayat dan hak-hak yang serupa itu dari masyarakat-masyarakat hukum adat, sepanjang menurut kenyataannya masih ada, harus sedemikian rupa sehingga sesuai dengan kepentingan nasional dan negara, yang berdasarkan atas persatuan bangsa serta tidak boleh bertentangan dengan undang-undang dan peraturan-peraturan lain yang lebih tinggi.

Kedudukan yang jelas tersebut juga berdampak positif kepada pemanfaatan hutan adat oleh masyarakat hukum adat. Dengan kedudukan demikian, pemanfaatan hutan adat hak ulayat oleh masyarakat hukum adat setempat tidak bertentangan dengan peraturan perundang-undangan. Pemanfaatan dilakukan berdasarkan hukum adat yang berlaku pada masing-masing masyarakat hukum adat. Tidak ada 
kewajiban untuk mengajukan permohonan guna mendapat penetapan status sebagai hutan adat, karena hutan adat hadir secara alami tanpa perlu diberikan atau ]pun dimohonkan kepada pemerintah. Namun bukan berarti tidak ada rambu-rambu hukum yang berlaku nasional (hukum positif) yang mengakibatkan masyarakat hukum adat bebas melakukan pemanfaatan dengan cara-cara yang dapat merusak hutan. Saat perusakan hutan dilakukan, hukum sudah siap ditegakkan.

\section{DAFTAR PUSTAKA}

Hadikusuma, Hilman. (1995). Metode Pembuatan Kertas Kerja atau Skrpsi Ilmu Hukum. Bandung: Mandar Maju.

Hadikusuma, Hilman. (2001). Hukum Perekonomian Adat Indonesia. Bandung : Citra Aditya Bakti.

Peraturan Menteri Lingkungan Hidup dan Kehutanan Nomor: P.32/MENLHKSETJEN/2015 Tahun 2015 tentang Hutan Hak.

Peraturan Menteri Lingkungan Hidup dan Kehutanan Nomor P.83/MENLHK/SETJEN/KUM.1/10/2016 tentang Perhutanan Sosial.

Peraturan Menteri (Permen) LHK Nomor 20 tahun 2018 tentang Jenis Tumbuhan dan Satwa yang dilindungi.

Sulaiman, Muhammad Adli, Teuku Muttaqin Mansur. (2019). Ketidakteraturan Hukum Pengakuan Dan Perlindungan Masyarakat Hukum Adat di Indonesia. Law Reform, Volume 15. Nomor 1, Fakultas Hukum Universitas Diponegoro.

Suratman, (2012). Metode Penelitian Hukum. Bandung: Alfabeta.

Undang-Undang Nomor 5 Tahun 1960 tentang Peraturan Dasar Pokok-pokok Agraria.

Undang-Undang Nomor 41 Tahun 1999 tentang Kehutanan sebagaimana telah diubah dengan Undang-Undang Nomor 19 Tahun 2004 tentang Penetapan Peraturan Pemerintah Pengganti UndangUndang Nomor 1 Tahun 2004 tentang Perubahan atas Undang-undang Nomor 41 Tahun 1999 tentang Kehutanan Menjadi Undang-Undang.

Undang-Undang Nomor 18 Tahun 2013 Tentang Pencegahan dan Pemberantasan Perusakan Hutan. 